\title{
An Educational Perspective on the Korean Classical Poetry and Songs in the Revision Literature Textbooks of 2015 Curriculum
}

\author{
Chung, So-Yeon \\ Ewha Womans University, Depts. of Korean Education \\ chong33@ewha.ac.kr
}

\begin{abstract}
This study examined the current state of classical poetry education in the Literature textbooks of 2015 revised curriculum. It was confirmed that the contents of Goryeo Gayo is the part where active participation, appreciation, and comprehensive inquiry of the learner emphasized in the revised curriculum are reflected most excellently. In particular, the Goryeo Gayo section was designed to explore the identity of Korean poetry before Hangul and to explore the identity of Korean literature by comparing it with Chinese poetry or poetry translated into Chinese. And this part, by allowing the learners to concern with the correlation between Hangul, Chinese text, spoken and written language, poetry and song, is composed highly organically to help learners to understand the general trend of the history of literature, while comprehensively grasping how the universality of Korean literature as a national literature is revealed in Classical Poetry.
\end{abstract}

Keywords: Korean classical poetry and songs, history of poetic literature, the universality of Korean poetic literature, the specialty of Korean poetic literature, continuation of literary history, learner's active involvement, integrated thought

\section{Introduction}

The difference between present and past would be a biggest concern. This study, especially, focuses on the education of Korean Classical Poetry. The proportion of the Korean Classical Poetry has been less than that of modern poetry. Aside from the physical amount of time accompanied by the literature history, it is reasonable to expect that the both poetries account for halves, respectively. The proportion of the works based on the contained in the text, however, shows that the number of modern poetry is much higher than that of Korean Classical Poetry. Considering these worse position of the Korean Classical Poetry, a survey of the current situation in the revised Literature textbooks is a measure of current interest and direction in Korean Classical Poetry and even education of classics in literary education. The revised literary textbooks, however, have not yet been reviewed, and especially the discussion of Korean Classical Poetry education has not been addressed at all, making such discussions to be urgent.

This study explores the current status of Korean Classical Poetry in the revised Literature textbooks. The most interesting question is the way the specialty and universality of Korean Classical Poetry are addressed and compared with modern poetry. In general, the education of modern poetry mentions only 'poetry', while that of Korean Classical Poetry mentions the 'song'

Article history:

Received (January 18, 2019), Review Result (April 14, 2019), Accepted (May 9, 2019) 
as well as 'poetry'. In Korean Classical Poetry, the both poetry and singing are handled at the same time, the role of the song in modern poetry is reduced or, as its name implies, completely disappeared. This means that the element of 'song' should be emphasized in Korean Classical Poetry education. In the curriculum of Literature, the concepts, tradition, character, universality, and specificity of Korean literature always appear. In the Korean Classical Poetry education, the universality and specificity of Korean literature has an inseparable relation with this singing.

In classical poetry education, in addition to the characteristics of recorded literature, the characteristic of singing of classical music which is enjoyed in oral literature has recently attracted attention. In particular, the peculiarity of the 2015 revised curriculum are the learner's active participation, appreciation, and inquiry, which can be closely linked to the fact that Korean Classical Poetry has been regarded as a song by many people of that era. Park (2018)[1], as emphasized in Sung (1997) [2] and Kim (2016) [3], pointed out that the fact that the Korean Classical Poetry was enjoyed as a song not as a poetry was overlooked in the Literature education. Prior to this, Jeong (2013) emphasized that the element of song should be actively considered in sijo, a genre of Korean Classical Poetry that is most important in literary education [4]. In Joe \& Jeong (2017), a plan in Goryeo Sokyo education was sought considering the fact that the poetry was enjoyed as a song [5].

It is necessary to examine how these findings are reflected in the literature education, and this is more interesting topic for the Literature textbook, which is assumed to play central role in the literature education. Section 2, with this in mind, examines the position of Korean Classical Poetry in the revised Literature textbook of the 2015 revised curriculum, and, in Section 3 , the meaning and the complementary measures are presented with the conclusions.

\section{Overview of Korean Classical Poetry and Songs in 2019 Revised Literature Textbooks}

The differences between previous and revised Literature textbooks for the Korean Classical Poetry are found in many contents. Before discussing the differences, the Korean Classical Poetries contained in the revised texts are as follows:

\section{Table 1. Korean Classical Poetry and Songs in 2015 Revision Literature Textbooks}

\begin{tabular}{|c|c|c|c|c|c|c|c|c|c|c|c|}
\hline & $\mathrm{D}$ & $\mathrm{M}$ & B & $\mathrm{S}$ & $\mathrm{J}$ & $\mathrm{C}$ & $\begin{array}{c}\mathrm{C} \\
(\mathrm{K})\end{array}$ & $\begin{array}{l}\mathrm{C} \\
(\mathrm{J})\end{array}$ & $\mathrm{G}$ & $\mathrm{H}$ \\
\hline \multirow{3}{*}{$\begin{array}{l}\text { Ancient } \\
\text { Songs }\end{array}$} & Goo-ji-ga & $\bullet$ & & & (0) & & & & & & \\
\hline & $\begin{array}{c}\text { Gong-mu- } \\
\text { do-ha-ga }\end{array}$ & & • & & & & $\diamond$ & & (2) & & $\diamond$ \\
\hline & $\begin{array}{c}\text { Hwang-jo- } \\
\text { ga }\end{array}$ & & (0) & & & & & ○ & & & () \\
\hline \multirow{3}{*}{ Hyang-ga } & $\begin{array}{c}\text { Cheo-yong- } \\
\text { ga }\end{array}$ & $\diamond$ & (2) & & $\diamond$ & & & & & & \\
\hline & $\begin{array}{c}\text { Heon-hwa- } \\
\text { ga }\end{array}$ & & (0) & & & & & (?) & & & \\
\hline & $\begin{array}{l}\text { Chan-gi-pa- } \\
\text { rang-ga }\end{array}$ & $\diamond$ & $\bullet$ & $\diamond$ & $\bullet$ & & & $\diamond$ & $\diamond$ & $\bullet$ & $\diamond$ \\
\hline
\end{tabular}




\begin{tabular}{|c|c|c|c|c|c|c|c|c|c|c|c|}
\hline & $\begin{array}{l}\text { Jae-man- } \\
\text { mae-ga }\end{array}$ & $\bullet$ & & $\bullet$ & & $\bullet$ & $\bullet$ & $\bullet$ & & & $\bullet$ \\
\hline \multirow{7}{*}{$\begin{array}{c}\text { Goryeo } \\
\text { Gayo }\end{array}$} & $\begin{array}{c}\text { Jeong-eup- } \\
\text { sa }\end{array}$ & & & $\bullet$ & & & $\bullet$ & & & & \\
\hline & Dong-dong & & & $\bullet$ & ( ) & & & & & & \\
\hline & Ga-si-ri & $\diamond$ & & () & $\diamond$ & & & & & & \\
\hline & $\begin{array}{c}\text { Cheong-san- } \\
\text { byeol-gok }\end{array}$ & & $\bullet$ & $\bullet$ & & $\bullet$ & () & & & & $\diamond$ \\
\hline & $\begin{array}{c}\text { Jeong-seok- } \\
\text { ga }\end{array}$ & & & & $\diamond$ & & & (2) & (?) & (2) & $\bullet$ \\
\hline & $\begin{array}{c}\text { Seo-gyeong- } \\
\text { byeol-gok }\end{array}$ & $\bullet$ & & & $\bullet$ & & & $\bullet$ & $\bullet$ & & $\diamond$ \\
\hline & $\begin{array}{l}\text { Jeong-gwa- } \\
\text { Jeong }\end{array}$ & & & & & & & & & & $\diamond$ \\
\hline $\begin{array}{l}\text { Gyeong-gi } \\
\text { chaega }\end{array}$ & $\begin{array}{l}\text { Han-lim- } \\
\text { byeol-gok }\end{array}$ & & & & & & & () & & & \\
\hline \multirow{7}{*}{ Sijo } & $\begin{array}{l}\text { Baek-seol-i } \\
\text { man-a-jin } \\
\text { gol-jja-gi- } \\
\text { aen /Lee } \\
\text { Saek }\end{array}$ & & & & & & $\bullet$ & & & & \\
\hline & $\begin{array}{c}\text { Chun-san-ae } \\
\text { noon nog-in } \\
\text { ba-ram / } \\
\text { Woo Tak }\end{array}$ & & $\bullet$ & & & & & & & & \\
\hline & $\begin{array}{l}\text { Sip-nyeon- } \\
\text { eul gyeong- } \\
\text { young-ha- } \\
\text { yeo / Song } \\
\text { Soon } \\
\end{array}$ & $\diamond$ & & & & & & & & $\bullet$ & \\
\hline & $\begin{array}{l}\text { Soo-yang- } \\
\text { san ba-ra- } \\
\text { bo-myeo / } \\
\text { Seong Sam- } \\
\text { moon }\end{array}$ & & $\bullet$ & $\bullet$ & & & & & & & $\bullet$ \\
\hline & $\begin{array}{l}\text { Do-san-sib- } \\
\text { i-gok / Lee } \\
\text { Hwang }\end{array}$ & & & & & & & & $\stackrel{\bullet}{(1)}$ & & \\
\hline & $\begin{array}{c}\text { Go-san-goo- } \\
\text { gok-ga / Lee } \\
\text { lee }\end{array}$ & & & & & & & & $\diamond$ & & \\
\hline & $\begin{array}{c}\text { Nae ma-eum } \\
\text { bae-eo-nae- }\end{array}$ & & & () & & & & & & & \\
\hline
\end{tabular}


An Educational Perspective on the Korean Classical Poetry and Songs in the Revision Literature Textbooks of 2015 Curriculum

\begin{tabular}{|c|c|c|c|c|c|c|c|c|c|c|c|}
\hline & $\begin{array}{c}\text { eo/ Jeong } \\
\text { Cheol }\end{array}$ & & & & & & & & & & \\
\hline & $\begin{array}{c}\text { A-chim-eun } \\
\text { B O-deo-ni / } \\
\text { Shin Heum }\end{array}$ & & & & & & & (0) & & & \\
\hline & $\begin{array}{c}\text { Eo-bu-sa-si- } \\
\text { sa / Yoon } \\
\text { Seondo }\end{array}$ & & $\bullet$ & & & $\stackrel{\bullet}{(4)}$ & & $\bullet$ & & & $\diamond$ \\
\hline & $\begin{array}{c}\text { Man-heung / } \\
\text { Yoon } \\
\text { Seondo }\end{array}$ & $\stackrel{\bullet}{(2)}$ & & $\stackrel{\bullet}{(3)}$ & $\stackrel{\bullet}{(3)}$ & & $\stackrel{\bullet}{(1)}$ & & (2) & & \\
\hline & \begin{tabular}{|c} 
Baek-goo-ya \\
Mal mool- \\
eo-bo-ja / \\
Kim \\
Cheontaek \\
\end{tabular} & & & & & & & & & & $\bullet$ \\
\hline & $\begin{array}{c}\text { Eo-jeo nae } \\
\text { il-i-ya / } \\
\text { Hwang Jin } \\
\text { lee }\end{array}$ & $\bullet$ & & & • & & & & & & $\bullet$ \\
\hline & $\begin{array}{c}\text { Dong-ji-nal } \\
\text { gi-na-gin } \\
\text { bam-eul / } \\
\text { Hwang Jin } \\
\text { lee } \\
\end{array}$ & & & & & & & $\bullet$ & & & \\
\hline & $\begin{array}{c}\text { Moet-beo- } \\
\text { deul ga-ryeo } \\
\text { GGeok-eo / } \\
\text { Hong Rang }\end{array}$ & & $\bullet$ & & & & & & $\bullet$ & & \\
\hline & \begin{tabular}{|} 
Lee-haw- \\
woo Heut- \\
bbu-lil ddae \\
/ Gye Lang
\end{tabular} & & & $\bullet$ & & & & & & & \\
\hline & $\begin{array}{l}\text { Ni-mo-do } \\
\text { dol-do jeon- } \\
\text { hyeo eob- } \\
\text { neun }\end{array}$ & & & & & & & • & & $\bullet$ & \\
\hline Saseol- & $\begin{array}{l}\text { Nim-i o-ma- } \\
\text { ha-geo-neul }\end{array}$ & $\bullet$ & & & & & $\bullet$ & & & & \\
\hline sijo & $\begin{array}{l}\text { Eo-i mot o- } \\
\text { deon-ga }\end{array}$ & & $\bullet$ & & & & & & & & \\
\hline & $\begin{array}{l}\text { Chang nae- } \\
\text { go-ja chang- } \\
\text { eul nae-go- } \\
\text { ja }\end{array}$ & & & $\bullet$ & & (?) & & & $\diamond$ & & $\bullet$ \\
\hline
\end{tabular}




\begin{tabular}{|c|c|c|c|c|c|c|c|c|c|c|c|}
\hline & $\begin{array}{c}\text { Il-sin-i sal-ja } \\
\text { ha-yeot-deo- } \\
\text { ni }\end{array}$ & & & & $\bullet$ & & & & & & \\
\hline & $\begin{array}{c}\text { Han-sum-a } \\
\text { ga-neu-da- } \\
\text { ran han- } \\
\text { sum-a }\end{array}$ & & & & & & & & $\bullet$ & & \\
\hline & $\begin{array}{c}\text { Doo-teo-bi } \\
\text { Pa-li-leul } \\
\text { mool-go }\end{array}$ & & & $\diamond$ & & & & & & & \\
\hline & $\begin{array}{c}\text { Bal-ga-beot- } \\
\text { eun a-i-deul- } \\
\mathrm{i}\end{array}$ & & & & $\diamond$ & & & & & & \\
\hline & \begin{tabular}{|c|} 
Sang-choon- \\
gok / Song \\
Soon \\
\end{tabular} & & & & & & & $\bullet$ & & & \\
\hline & $\begin{array}{c}\text { Sa-mi-in- } \\
\text { gok / Jeong } \\
\text { Cheol }\end{array}$ & & $\bullet$ & & & $\bullet$ & & & & & \\
\hline Ga-sa & $\begin{array}{c}\text { Sok-mi-in- } \\
\text { gok / Jeong } \\
\text { Cheol }\end{array}$ & $\bullet$ & & $\bullet$ & $\bullet$ & & $\diamond$ & & $\bullet$ & & \\
\hline & $\begin{array}{l}\text { Noo-hang-sa } \\
\text { / Park Inro }\end{array}$ & & & () & & & & & & & \\
\hline & $\begin{array}{l}\text { Man-eon-sa } \\
\text { / An Johwan }\end{array}$ & & & & & & & () & & & \\
\hline & $\begin{array}{c}\text { Gyu-won-ga } \\
\text { / Heo } \\
\text { Nanseolheon }\end{array}$ & $\diamond$ & & & & & & & & $\bullet$ & $\bullet$ \\
\hline Folk Song & $\begin{array}{l}\text { Jeongseon } \\
\text { arirang }\end{array}$ & & & & $\diamond$ & $\bullet$ & $\diamond$ & & $\bullet$ & & \\
\hline & $\begin{array}{c}\text { Jae-ga-ya- } \\
\text { san-dok-seo- } \\
\text { dang / Choi } \\
\text { Chiwon }\end{array}$ & & $\bullet$ & & & & & & & & \\
\hline Hansi & $\begin{array}{c}\text { Chok-gyu- } \\
\text { hwa / Choi } \\
\text { Chiwon }\end{array}$ & & & & & & & & $\bullet$ & & \\
\hline & \begin{tabular}{|c||} 
Choo-ya- \\
woo-joong / \\
Choi \\
Chiwon
\end{tabular} & & & & & & & & & & $\diamond$ \\
\hline & \begin{tabular}{|c|} 
Song-in / \\
Jeong Jisang
\end{tabular} & (0) & & & & $\bullet$ & $\diamond$ & & & & $\diamond$ \\
\hline
\end{tabular}




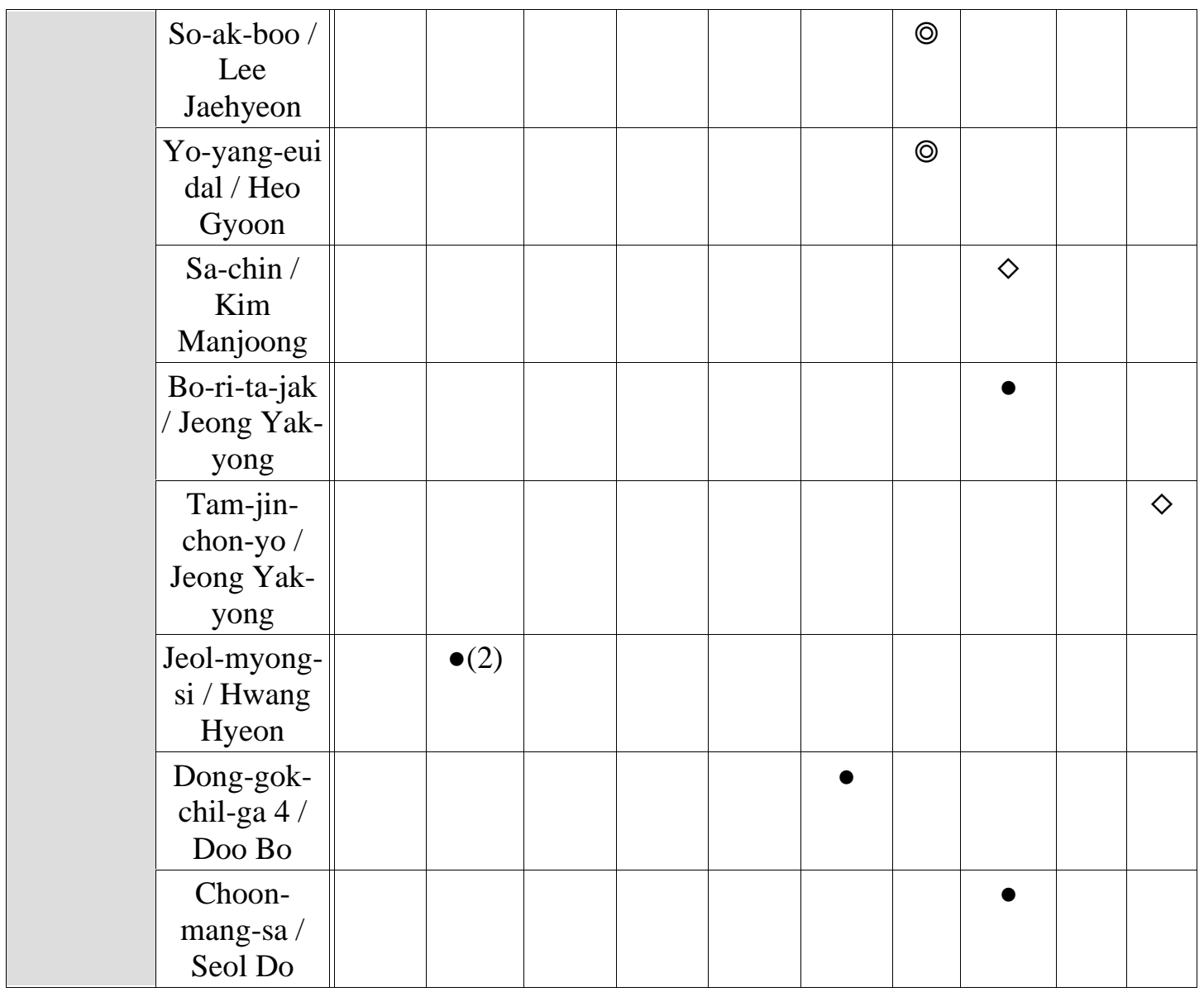

D: Dong-A, M: Mirae-en, B: Bisang, S: Shinsago, J: Jihaksa, C: Changbi, C(K): Cheonjae (Kim), C(J): Cheonjae (Jeong), G: Geumseong, H: Haename-Edu

•: main works, @: student activities's works: $\diamond$ : the others, (): the numbers of same title's work

In the previous curriculum, Sijo was emphasized as the most representative genre of Korean Classical Poetry, while in revised curriculum, the number of works by genre is more balanced. Assuming that Saseol-Sijo is included in Sijo, Sijo is the most common part, however, all textbooks sought to refer to each genre though the specific works are not contained in the text. The reason that the proportion of Sijo was overwhelmingly high in the past is not only because of the fact that Sijo is a national genre representing the Korean Classical Poetry, but also that the number of works handed down is much higher than other genres. For this aspect, the comparison with Koryo Gayo, which has a relatively small number of available works, shows that the prejudice toward Sijo is weakened, evidenced by the findings that the number of works of Sijo and Goryeo Gayo in each textbook is similar as 3-4 pieces. For the Ga-sa genre, the high bias is remained because, as with Pyeong-Sijo, the works from late Choseon period are not addressed. A genre that is addressed relatively more compared to past is Goryeo Gayo. In addition to the adoption of more works than the Pyeong-shijo, activities to deepen the learner's thinking, inquiry, and active participation were strengthened.

\section{Conclusion}

This study examined the current state of classical poetry education in the Literature textbooks of 2015 revised curriculum. It was confirmed that the contents of Koryeo is the s part 
where active participation, appreciation, and comprehensive inquiry of the learner emphasized in the revised curriculum are reflected most excllently. In particular, the Goryeo Gayo section was designed to explore the identity of Korean poetry before Hangul and to explore the identity of Korean literature by comparing it with Chinese poetry or poetry translated into Chinese. And this part, by allowing the learners to concerned with the correlation between Hangul, Chinese text, spoken and written language, poetry and song, is composed highly organically to help learners to understand the general trend of the history of literature, while comprehensively grasping how the universality of Korean literature as a national literature is revealed in Classical Poetry.

\section{References}

[1] G. J. Park. Korean Classical Literature and Education. 38 (2018)

[2] H. G. Seoung. Korean Classical Literature Study. 12 (1997)

[3] H. S. Kim. Korean Poetry and Songs Study. 41(2016)

[4] S. Y. Chung. Korean Classical Literature and Education. 24 (2012)

[5] E. J. Cho and S. Y. Chung. Asia-pacific Journal of Multimedia services convergent with Art, Humanities, and Sociology. 7, 2 (2017)

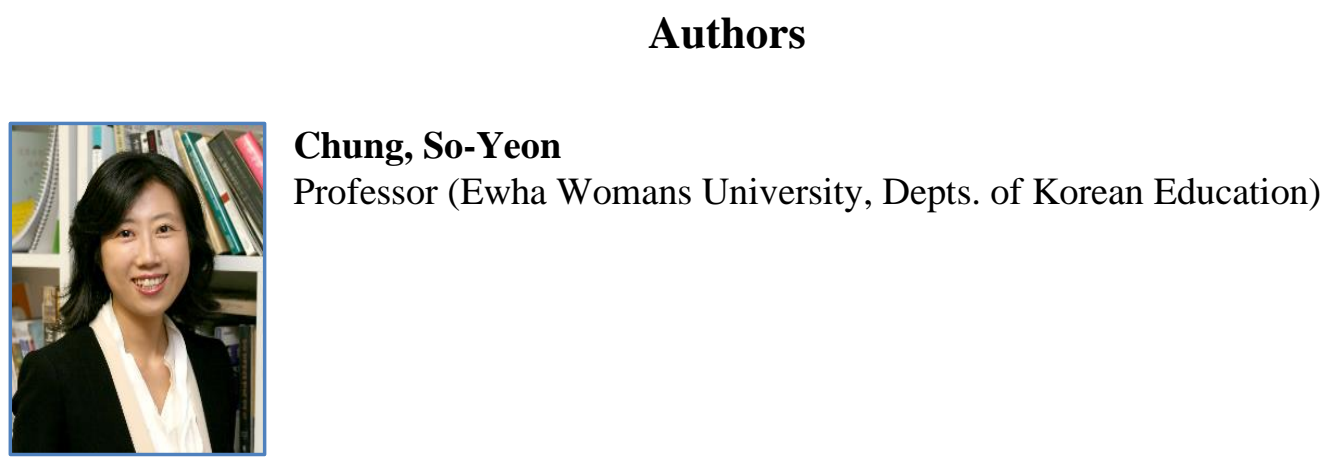


An Educational Perspective on the Korean Classical Poetry and Songs in the Revision Literature Textbooks of 2015 Curriculum 